\title{
Evaluation of the Role of Whole Body Computed Tomography in the Management of Minor Trauma Patients
}

\section{Minör Travma Hastalarının Yönetiminde Tüm Vücut Bilgisayarlı Tomografinin Rolünün Değerlendirilmesi}

\author{
Gökhan Aksel', @ibrahim Altunok', @Şeref Kerem Çorbacıoğlu², @Hatice Şeyma Akça',

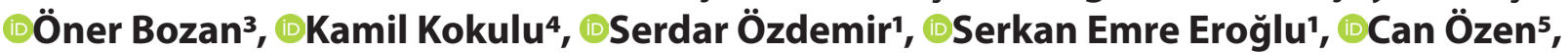 \\ Mehmet Muzaffer İslam \\ UUniversity of Health Sciences, Umraniye Training and Research Hospital, Department of Emergency Medicine, Istanbul, Turkey \\ 2University of Health Sciences, Kecioren Training and Research Hospital, Department of Emergency Medicine, Istanbul, Turkey \\ ${ }^{3}$ University of Health Sciences, Okmeydani Training and Research Hospital, Department of Emergency Medicine, Istanbul, Turkey \\ ${ }^{4}$ Aksaray University, School of Medicine, Department of Emergency Medicine, Aksaray, Turkey \\ ${ }^{5}$ King's College Hospital, Department of Emergency, London, United Kingdom
}

\begin{abstract}
Aim: Whole body of computed tomography (WBCT) approach is increasingly being preferred by the clinicians over the traditional selected CT approach worldwide, not only for major trauma patients but even for minor trauma patients. Our aim was to determine the ratio of polytrauma patients in minor trauma patients imaged with WBCT and to determine demographical and clinical predictors of polytrauma.
\end{abstract}

Material and Method:This retrospective-descriptive-study was conducted at the emergency department with patients older than 16 but had an injury severity scores of less than 16 and those who underwent WBCT trauma patients between January 2015 and December 2018. The presence of polytrauma, which defined presence of injury with an abbreviated injury scale score $\geq 2$ according to tomography results in at least two body regions, was considered as the primary outcome of the study.

Results: Total 3924 patients' data were enrolled in the study. Only in 278 of all patients (7.1\%) polytrauma was detected. After the multi-logistic regression analysis, fall from height ( $>3$ meters), pedestrian struck, altered mental status (GCS $<14)$, and male sex were found as significant predictor factors for presence of polytrauma. When created a model with these parameters, it was found that it had low diagnostic accuracy value as 0.6 ( $95 \% \mathrm{Cl}: 0.59$ to 0.72 ).

Conclusion: When considered only minor trauma patients with small polytrauma and mortality ratio, routine using of WBCT approach is not rational. The predictors found in our study can be used to develop a clinical decision rule in the future for minor trauma patients.

Keywords: Whole body computed tomography, pan- $\mathrm{CT}$, tomography, $\mathrm{X}$ ray computed, multiple traumas, radiation exposure, polytrauma, emergency departments

\section{Öz}

Amaç:Tüm vücut bilgisayarlı tomografi (TVBT) yaklaşımı, klinisyenler tarafından sadece majör travma hastaları için değil, hatta minör travma hastaları için de dünya çapında geleneksel seçilmiş BT yaklaşımına göre giderek daha fazla tercih edilmektedir. Amacımız, TVBT ile görüntülenen minör travma hastalarında çoklu travma hastalarının oranını belirlemek ve çoklu travmanın demografik ve klinik belirleyicilerini belirlemekti.

Gereç ve Yöntem: Bu retrospektif-tanımlayıcı-çalışma, acil serviste 16 yaşından büyük ancak injury severty skoru < 16 olan ve Ocak 2015 ile Aralık 2018 tarihleri arasında, WBCT çekilmiş olan travma hastalarının verileri incelenerek yapıldı. En az iki vücut bölgesinde tomografi sonuçlarına göre abbreviated injury scale skoru $\geq 2$ olan yaralanma varlığı çalışmanın birincil sonlanımı olarak belirlendi.

Bulgular: Çalışmaya toplam 3924 hastanın verileri dahil edildi. Tüm hastaların sadece 278 'inde $(\% 7,1)$ çoklu travma tespit edildi. Çoklu lojistik regresyon analiz sonuçlarına göre, yüksekten düşme (>3 metre), yayaya araç çarpması, değişen mental durum (GCS <14) ve erkek cinsiyet, çoklu travma varlığı için anlamlı değişkenler olarak bulundu. Bu değişkenlerle bir model oluşturulduğunda, bu modelin 0,6 (\%95 Cl: 0,59 ila 0,72) gibi düşük tanısal doğruluk değerine sahip olduğu bulunmuştur.

Sonuç: Çoklu travma ve mortalite oranı küçük olan sadece minör travma hastaları düşünüldüğünde, TVBT yaklaşımının rutin kullanımı akılcı değildir. Çalışmamızda bulunan prediktörler, minör travma hastaları için gelecekte klinik bir karar kuralı geliştirmek için kullanılabilir.

Anahtar Kelimeler: Tüm vücut bilgisayarlı tomografi, pan-CT, çoklu travma, radyasyon maruziyeti, politravma, acil tıp

Corresponding (illetişim): Gökhan Aksel, Emergency Medicine Department, University of Health Sciences, Umraniye Training and Research Hospital, Istanbul, Turkey

E-mail (E-posta): aksel@gokhanaksel.com

Received (Geliş Tarihi): 09.08.2021Ａccepted (Kabul Tarihi): 28.08.2021 


\section{INTRODUCTION}

The whole-body computed tomography (WBCT) which consists of unenhanced head and cervical, and contrastenhanced chest, abdomen, and pelvis computed tomography $(\mathrm{CT})$, is an important imaging option in the management of multiple trauma patients. Contrary this approach, the traditional selected CT (SCT) approach of the ATLS is primarily to order conventional radiographs and focused abdominal sonography in trauma (FAST), and then to perform CT of the relevant body region within the indication..$^{[1,2]}$ However, superiority of WBCT to SCT approach is still controversial. The main concerns about WBCT approach can be summarized as unnecessary radiation exposure it may cause and inadequate data on its mortality and morbidity benefit.. ${ }^{[3]}$ Conflicting results regarding the effect of WBCT on mortality rates have been reported in the study results, which were mostly retrospective in the literature. ${ }^{[4-11]}$ Although Sierink et al reported in their randomized controlled study (REACT-2 trial) that there was no significant difference on mortality between two approaches, the effect of WBCT approach on mortality and morbidity is still unclear. ${ }^{[12]}$

Despite this uncertainty in the literature, WBCT approach is increasingly being preferred by the clinicians over SCT approach worldwide. In fact, this preference is not only for major trauma patients but even for minor trauma patients. Among the possible reasons why WBCT is preferred even in minor trauma patients, some clinicians believe that WBCT may be advantageous in two issues; first, especially those such as crowded emergency departments in the US and Turkey, ${ }^{[13]}$ as SCT is a time-consuming approach, the WBCT approach decreases the emergency crowd by decreasing the patients' length of stay in the emergency department. Second, again, especially in these crowded emergency departments, it is thought that physicians working under intensive patient burden reduce the risk of misdiagnosis and prevent medicolegal problems when WBCT approach was preferred.

We aimed to analyze the data of minor trauma patients (injury severity score (ISS) <16) underwent WBCT by questioning the necessity of WBCT in these patients. The primary outcome of this study is to identify patients with polytrauma among these minor traumas. We aimed to determine, if detected, what parameters were present in the patient group, in which the WBCT approach was beneficial, the WBCT approach could detect patients with polytrauma.

\section{MATERIAL AND METHOD}

\section{Study design and setting}

This study was conducted at the emergency department (ED) of a tertiary care teaching hospital having annually 580,000 emergency patient admissions between January 2015 and December 2018. We examined the electronic records of patients admitted to the ED following local ethical committee approval.

\section{Selection of participants}

The hospital's electronic patient record management system was used for screening the data of the adult patients admitted to ED with trauma. The patients older than 16 but had an ISS of less than 16 and those who underwent WBCT were included in the study. Pregnant patients, duplicate applications and those with a lack of data were excluded from the study.

\section{Measurements}

Trauma patients who underwent unenhanced head and cervical, and contrast-enhanced chest, abdomen, and pelvis CTs were considered to be managed by the WBCT approach. All these CTs were accepted as WBCT protocol only if they were all taken with the same protocol and none were missing.

Five researchers who were emergency physicians with at least 3 years of experience were trained to collect data from the hospital data-registration system and to calculate the ISS of the patients before the study period. They scanned all trauma patients who underwent WBCT during the study period and calculated the ISS according to patients'WBCT results reported by a radiologist and physical examination records. When the agreement of the researchers in the calculation of the ISS is calculated with 100 same patients, the intraclass correlation was found good (intraclass correlation $=0.793$ ).

\section{Outcomes}

We determined the presence of polytrauma as the primary outcome of the study, as the potential benefit of the WBCT approach is thought to diagnose injuries in other systems outside the body region where the primary injury is. We defined polytrauma as the presence of injury with an Abbreviated Injury Scale (AIS) $\geq 2$ according to tomography results in at least two body regions. ${ }^{[14]}$ Accordingly, patients were divided into two groups; those with and without polytrauma. By determining which variables can predict the presence of polytrauma, we aimed to determine which patients could benefit from WBCT.

\section{Analysis}

All data were analyzed by IBM SPSS Statistics for Mac, version 25.0 for Mac OS X (IBM Corp., Armonk, N.Y., USA). The normality of the data distribution was determined by the Shapiro-Wilk test, histogram, and Q-Q plots. The categorical values of the patients were expressed as a number and a percentage and were analyzed with a Chi-square test. Continued values were presented as a mean and standard deviation or median values and an inter quartile range of $25 \%-75 \%$. The non-parametric values were analyzed using the Mann-Whitney $U$, and the parametric ones with $T$ test. To determine the predictive value of several variables, a multivariate regression model was created using variables whose $p$ value was $<0.1$ in univariate analyses. To assess the model's goodness of fit, the HosmerLemeshow test was performed. A two-tailed $p$ value $<0.05$ was considered statistically significant. 


\section{RESULTS}

In study period, 3924 minor trauma patients (ISS<16) who admitted to our emergency department due to several trauma reasons and underwent WBCT were enrolled in the study. The median age of patients was 33 (IQR25-75\%: 24 to 46$)$ and 2979 (75.9\%) of them were male. Although there were no significant injuries after evaluation of WBCT in 2618 of all patients $(66.7 \%)$, several injuries were detected in 1306 patients (33.3\%), and only in 278 of all patients (\%7.1), injuries of multiple body parts were detected and accepted as polytrauma. Baseline characteristics of all patients were shown on Table 1.

When several demographical and clinical characteristics of patients were analyzed according to presence of polytrauma, significantly differences were found terms of several parameters between both groups and they were summarized in Table 2. To determine the potential variables for prediction of polytrauma, a multivariate logistic regression model was created. Fall from height ( $>3$ meters), pedestrian struck, motor vehicle collision, altered mental status (GCS <14), male sex, and age over 65 years were included to initial model. In addition, even though significant difference was found terms of serum lactate level, $\mathrm{pH}$, base excess, and vital signs between both groups in Table 1, these variables were not included to model, because these values were not examined in all patients, only in 574 patients for venous blood gases analysis, in 3085 patients for oxygen saturation, in 1467 patients for respiratory rate, and in 3298 patients for pulse rate. The data of these variables were presented as only univariate analysis in Table 2. Overall, according to final model, fall from height (>3 meters), pedestrian struck, altered mental status (GCS $<14$ ), and male sex were found as significant predictor factors for polytrauma (Table 3).

\begin{tabular}{|c|c|c|c|}
\hline Variables & N:3924 & Variables & N:3924 \\
\hline Gender N (\%) & & Injuries detected by WBCT N (\%) & \\
\hline Male & 2979 (75.9) & Totally normal & $2618(66.7)$ \\
\hline Female & $945(24.1)$ & Intraparenchymal hemorrhage & $8(0.2)$ \\
\hline Age median (IQR 25-75\%) & 33 (24 to 46$)$ & Subdural hemorrhage & $33(0.8)$ \\
\hline Presence of comorbidities N (\%) & $170(4.3)$ & Epidural hemorrhage & $23(0.6)$ \\
\hline Chronic hypertension & $99(2.5)$ & Subarachnoid hemorrhage & $57(1.5)$ \\
\hline Diabetes mellitus & $65(1.7)$ & Cerebral contusion & $29(0.7)$ \\
\hline Coronary artery disease & $35(0.9)$ & Compression fracture & $9(0.2)$ \\
\hline Chronic kidney disease & $10(0.3)$ & Linear fracture & $102(2.6)$ \\
\hline Stroke & $8(0.2)$ & Cervical spine fracture & $29(0.7)$ \\
\hline Congestive heart failure & $9(0.2)$ & Cervical Spondylolisthesis & $1(0.0)$ \\
\hline COPD & $15(0.4)$ & Thoracolumbar spine fracture & 297 (7.6) \\
\hline Mental retardation & $5(0.1)$ & Thoracolumbar spondylolisthesis & $7(0.2)$ \\
\hline Use of anti-thrombotic agent $\mathrm{N}(\%)$ & & Cot fractures (less than 3 ) & $108(2.8)$ \\
\hline Anticoagulant agent & $10(0.3)$ & Multiple cot fractures (3 or more) & $74(1.9)$ \\
\hline Antiplatelet agent & $19(0.5)$ & Hemothorax & $45(1.1)$ \\
\hline Trauma mechanism N (\%) & & Pneumothorax & $76(1.9)$ \\
\hline Motor vehicle collision & $1440(36.7)$ & Pulmonary contusion & $232(5.9)$ \\
\hline Pedestrian struck & $532(13.6)$ & Intra-abdominal solid organ injury & $41(1)$ \\
\hline Fall from height ( $\geq 3$ meters) & $315(8)$ & Gastrointestinal tract injury & $2(0.1)$ \\
\hline Fall from height ( $<3$ meters) & $416(10.6)$ & Renal injury & $5(0.1)$ \\
\hline Fall from same level & $203(5.2)$ & Bladder injury & $1(0.0)$ \\
\hline Motorcycle accident & $617(15.7)$ & Bone fractures of extremities & $665(17)$ \\
\hline Bicycle accident & $38(1)$ & Maxillofacial fractures & $97(2.5)$ \\
\hline Violence & $238(6.1)$ & Patients outcomes N (\%) & \\
\hline Other & $125(3.2)$ & Exitus in ED & $2(0.1)$ \\
\hline Vital signs on admission median (IQR 25-75 & & Admission to ICU & $51(1.3)$ \\
\hline Respiratory rate (for 1467 patients) & 17 (15 to 18$)$ & Admission to hospital bed & $529(13.5)$ \\
\hline Pulse rate (for 3298 patients) & 80 (76 to 88$)$ & Transfer to another hospital & $25(0.6)$ \\
\hline Oxygen saturation \% (for 3085 patients) & 98 (97 to 99) & Treatment refusal & $188(4.8)$ \\
\hline Systolic blood pressure (for 3394 patients) & 123 (119 to 132$)$ & Discharged from ED & $3129(79.7)$ \\
\hline Diastolic blood pressure (for 3394 patients) & 76 (70 to 80$)$ & Polytrauma N (\%) & $278(7.1)$ \\
\hline Glasgow coma scale median (min-max) & 15 (3 to 15$)$ & Mortality N (\%) & \\
\hline ISS median (IQR 25-75\%) & $2(1$ to 5$)$ & Mortality within 30 day & $11(0.3)$ \\
\hline \multicolumn{2}{|c|}{ Laboratory findings on admission median (IQR 25-75\%) } & Mortality within first 24 hours & $3(0.1)$ \\
\hline pH (for 574 patients) & $7.38(7.35$ to 7.42$)$ & Mortality in hospital & $8(0.2)$ \\
\hline Base excess (for 574 patients) & $0.40(-1.6$ to 2.1$)$ & RBC Transfusion mean/median (min-max) & $0.9 / 0(0-21)$ \\
\hline Lactate (for 574 patients) & 2.0 (1.5 to 2.9$)$ & Need for intubation N (\%) & $33(0.8)$ \\
\hline Hemoglobin (for 3848 patients) & $14.2(13$ to 15.1$)$ & Need for operation $\mathbf{N}(\%)$ & $381(9.7)$ \\
\hline Hematocrit (for 3848 patients) & $42.3(39$ to 44$)$ & & \\
\hline INR (for 1427 patients) & $1.09(1.02$ to 1.19$)$ & & \\
\hline
\end{tabular}




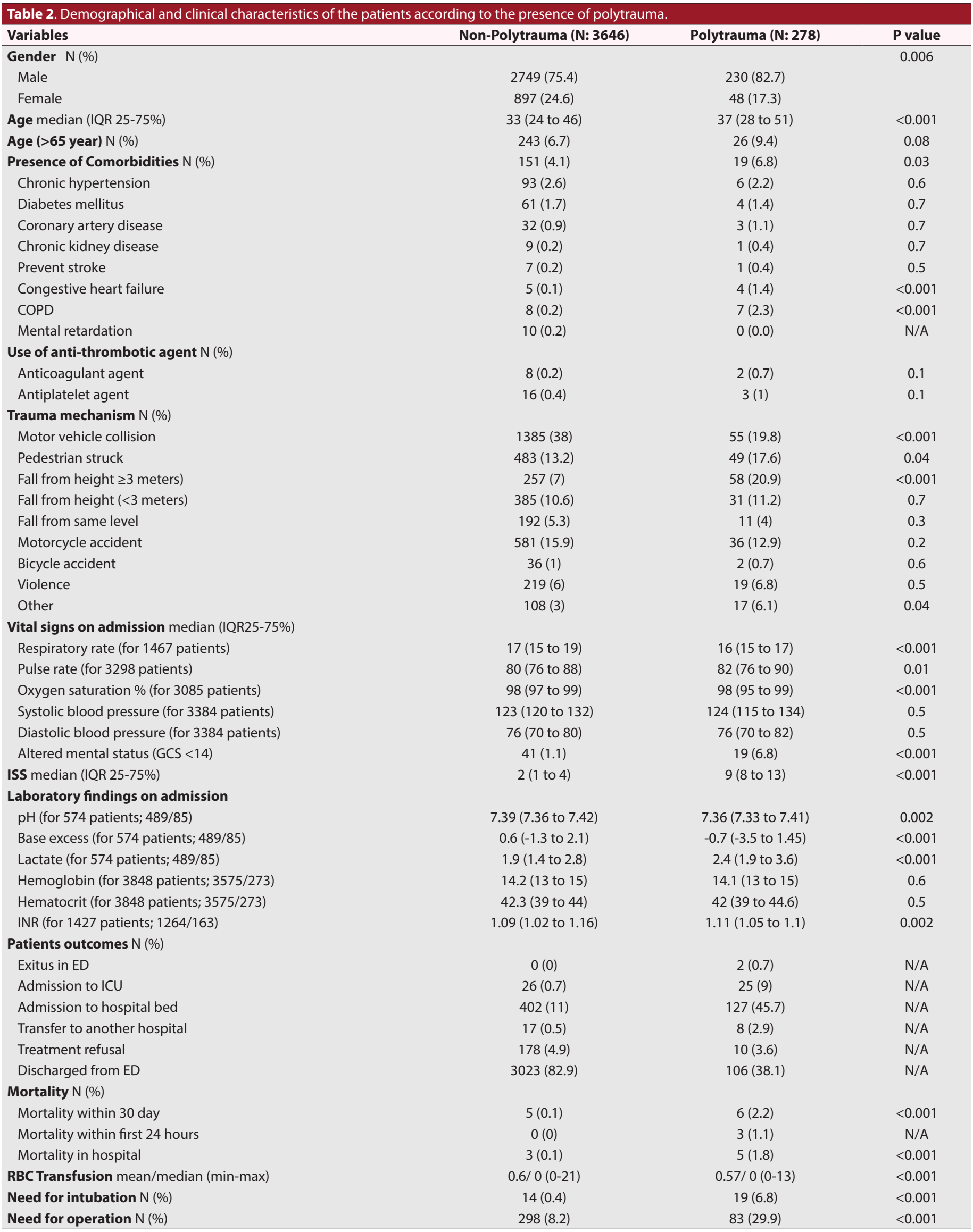




\begin{tabular}{lccc}
\hline $\begin{array}{l}\text { Table 3. Multivariate logistic regression to predict polytrauma in minor } \\
\text { trauma patients. }\end{array}$ & Wald & P value & OR (95\% CI) \\
\hline Fall from height (>3 meters) & 62.632 & 0.001 & $3.76(2.7$ to 5.2$)$ \\
Pedestrian struck & 10.323 & $<0.001$ & $1.76(1.2$ to 2.4$)$ \\
Altered mental status (GCS $<14)$ & 38.239 & $<0.001$ & $6.07(3.4$ to 10$)$ \\
Male sex & 7.121 & 0.008 & $1.57(1.18$ to 2.1$)$ \\
$>$ 65-year-old & 2.645 & 0.1 & $1.44(0.9$ to 2.2$)$ \\
\hline
\end{tabular}

When created a model with four parameters (presence of any parameters was accepted as prediction polytrauma and absence of all parameter was accepted as prediction nonpolytrauma), it was found that it had low diagnostic accuracy value as 0.6 ( $95 \% \mathrm{Cl}: 0.59$ to 0.72 ), other diagnostic values were as follows; sensitivity was $52 \%$ (95\%Cl: 46 to 58 ), specificity was $61 \%(95 \% \mathrm{Cl}: 59$ to 62$)$, negative likelihood ratio was 0.77 (95\%Cl: 0.68 to 87 ) and positive likelihood ratio was 1.37 (95\%Cl: 1.22 to 1.54$)$.

\section{DISCUSSION}

Although indications of WBCT criteria is not well defined and controversies are continued, routine use of WBCT approach is spreading in moderate and severe trauma patients. As a matter of fact, we - as the authors of this study - support this WBCT approaching in management of moderate and severe trauma patients. However, we notice with concern the situation is that this trend is spreading even in minor trauma patients to reduce the likelihood of misdiagnosis and to decrease delay, especially in overcrowded emergency services. Therefore, we decided to focus on minor trauma patients and query whether there is necessity of WBCT in management of minor trauma patients. Obviously, our study showed that the rate of negative or unnecessary WBCT was high as $66.7 \%$, rate of polytrauma was $\% 7.1$, and mortality rate was only $0.3 \%$ in minor trauma patients. The unnecessary or negative WBCT rate of the previously studies, which conducted with generally major trauma patients, was reported as lower than our results, ranging from 14 to $30 \%{ }^{[1,8,15,16]}$ Similarly, reported mortality rate in previously studies is too higher than our results, as ranged from 4.7 to $22 \%{ }^{[1,4,17]}$ When considered these data, it seems that contribution of routine WBCT using is too limited in management of minor trauma patients. Therefore, we believe that routine using of WBCT approach is not rational and when considered unnecessary radiation exposure, it may be harmful.

On the other hand, some authors in their well written review pointed out that diagnosing occult injuries with routine WBCT allows of safe and fast disposition from ED and obviates requiring of subsequent imaging and medical evaluation when patients present for follow-up with nonspecific pain or other complaints. ${ }^{[18]}$ And, rightly again, they concluded that even some minor injuries, that may be misdiagnosed when WBCT wasn't used, can be fatal in the special population. Similarly, in our study, though number is few, there were also polytrauma subjects $(7.1 \%)$ in minor trauma patients. Through our regression analysis, we have found four parameters (fall from height ( $>3$ meters), pedestrian struck, altered mental status (GCS $<14$ ), and male sex) that can predict which WBCT scanning have polytrauma. To our knowledge, there is no study focused only minor traumas investigating the effectiveness of WBCT. Previously studies aimed to develop a criterion for WBCT have generally focused on all trauma patients. In a prospective study, conducted by J. Babaud et al., the Vittel criteria, which consist of several preadmission physiological variables, trauma mechanism, anatomic location of injuries, and comorbidities, was evaluated to whether could be used to determine the need for WBCT. ${ }^{[19]}$ Finally, Glasgow Coma Scale (GCS) score less than 13, penetrating trauma, and resuscitation with greater than $1000 \mathrm{~mL}$ of colloids were found as independent predictor for needing WBCT. Another retrospective study was conducted by Davies et al., a model created and evaluated to detect significant injuries as a decision rule for WBCT in major trauma patients. ${ }^{[14]}$ After final regression model, five independent predictors of polytrauma clinical signs in more than one body region, GCS score $<14$, presence of hemodynamic abnormality (SBP $<100 \mathrm{mmHg}$, or heart rate $>100 \mathrm{bpm}$ ), presence of respiratory abnormality (respiratory rate $>24$ breaths $/ \mathrm{min}$, or $\mathrm{pSO}_{2}<93 \%$ ), and mechanism of the injury. However, when evaluated diagnostic accuracy of this model, the accuracy or the area under the curve (AUC) of the receiver operating characteristic $(\mathrm{ROC})$ was reported as 0.82 , with the sensitivity and specificity values of $79 \%$ and $71 \%$, respectively. Finally, in another retrospective study which was conducted by Hsiao et al. with 660 trauma patients, it was aimed to identify the independent predictors and create a diagnostic decision rule to detect needing WBCT. ${ }^{[11]}$ After regression analysis, independent predictors were defined as; male sex, GCS score $<9$, mechanism of the injury (fall $>5 \mathrm{~m}$ and being a cyclist). The accuracy of this model was reported as 0.74 (95\% Cl: 0.67-0.80). In addition, the authors reported the accuracy of only clinical decision trauma leader without any formal protocol as $0.70(95 \% \mathrm{Cl} 0.63-0.76)$ and they concluded that there was not any clinically significant contribution of their decision rule. Similarly, in our study, though we found four significant independent predictors, the accuracy of the model that created with them is found so low as 0.6.

Due to retrospective nature of this present study, several potential predictor factors could not be considered such as; detail of trauma mechanism (vehicleestimated speed, presence helmet/seat belt), detail of resuscitation in prehospital period, etc. When considered our predictors inadequate to explain variance on outcome variable (polytrauma) in our model, these potential predictors might have been explained to important part of variance on outcome variable. Similarly, though vital signs and several laboratory results on admission were evaluated in this study, these potential predictors could not be included to model since there is no record for every patient. Finally, another potential limitation is that ISS values were calculated retrospectively based on CT findings and medical records. 


\section{CONCLUSION}

As a conclusion, when considered the results of previous and present studies, though it seems that several predictors including trauma mechanism, clinical findings on admission, laboratory examining in the early period of resuscitation are related to needing WBCT, models created with these predictors seem to be far from being sufficient for determine indication WBCT. When considered only minor trauma patients with small polytrauma and mortality ratio, routine using of WBCT approach is not rational and when considered unnecessary radiation exposure, it may be harmful. Though our data is not enough to suggest a decision model to determine needing of WBCT, we believe that predictors found in our study (fall from height (>3 meters), pedestrian struck, altered mental status (GCS score <14), and male sex), along with other possible predictors, can be used to develop a clinical decision rule in the future for minor trauma patients..

\section{ETHICAL DECLARATIONS}

Ethics Committee Approval: University of Health Sciences, Umraniye Training and Research Hospital, Clinical Research Ethics Committee, Approval date: 23.01.2019, Decision No: B.10.1.THK.4.34.H.GP.0.001/12.

Informed Consent: Because the study was designed retrospectively, no written informed consent form was obtained from patients.

Referee Evaluation Process: Externally peer-reviewed.

Conflict of Interest Statement: The authors have no conflicts of interest to declare.

Financial Disclosure: The authors declared that this study has received no financial support.

Author Contributions: All of the authors declare that they have all participated in the design, execution, and analysis of the paper, and that they have approved the final version.

\section{REFERENCES}

1. Smith CM, Woolrich-Burt L, Wellings R, Costa ML. Major trauma CT scanning: the experience of a regional trauma centre in the UK. Emerg Med J 2011;28:378-82.

2. Çorbacıoğlu SK, Er E, Aslan S, et al. The significance of routine thoracic computed tomography in patients with blunt chest trauma. Injury 2015;46:849-53.

3. Çorbacıoğlu ŞK, Aksel G. Whole body computed tomography in multi trauma patients: Review of the current literature. Turk J Emerg Med 2018;18:142-7.

4. Huber-Wagner S, Lefering R, Qvick L-M, et al. Effect of whole-body CT during trauma resuscitation on survival: a retrospective, multicentre study. The Lancet 2009;373:1455-61.

5. Huber-Wagner S, Biberthaler $\mathrm{P}$, Häberle $\mathrm{S}$, et al. Whole-Body $\mathrm{CT}$ in Haemodynamically Unstable Severely Injured Patients - A Retrospective, Multicentre Study. PLoS One 2013;8.

6. Weninger $\mathrm{P}$, Mauritz W, Fridrich $\mathrm{P}$, et al. Emergency room management of patients with blunt major trauma: evaluation of the multislice computed tomography protocol exemplified by an urban trauma center. J Trauma Acute Care Surg 2007;62:584-591.
7. Hutter M, Woltmann A, Hierholzer C, Gärtner C, Bühren V, Stengel D. Association between a single-pass whole-body computed tomography policy and survival after blunt major trauma: a retrospective cohort study. Scandinavian J Trauma Resuscitat Emerg Med 2011;19:73.

8. Wurmb TE, Frühwald P, Hopfner W, et al. Whole-body multislice computed tomography as the first line diagnostic tool in patients with multiple injuries: the focus on time. J Trauma Acute Care Surg 2009;66:658-65.

9. Mao Shanlin X, Xinfa XY, Hongfei W, Lijun L. The value of whole-body CT in severe traffic trauma patients during the early resuscitation phase. Chinese J Trauma 2012;28:269-71.

10. Kimura A, Tanaka N. Whole-body computed tomography is associated with decreased mortality in blunt trauma patients with moderate-tosevere consciousness disturbance: a multicenter, retrospective study. J Trauma Acute Care Surg 2013;75:202-6.

11. Hsiao KH, Dinh MM, McNamara KP, et al. Whole-body computed tomography in the initial assessment of trauma patients: Is there optimal criteria for patient selection? Emerg Med Australasia 2013;25:182-91.

12. Sierink JC, Treskes K, Edwards MJ, et al. Immediate total-body CT scanning versus conventional imaging and selective $C T$ scanning in patients with severe trauma (REACT-2): a randomised controlled trial. The Lancet 2016;388:673-83.

13. Aksel G, Bildik F, Demircan A, et al. Effects of fast-track in a university emergency department through the National Emergency Department Overcrowding Study. J Pak Med Assoc 2014;64:791-7.

14. Davies RM, Scrimshire AB, Sweetman L, Anderton MJ, Holt EM. A decision tool for whole-body $C T$ in major trauma that safely reduces unnecessary scanning and associated radiation risks: An initial exploratory analysis. Injury 2016;47:43-9.

15. Sampson MA, Colquhoun KBM, Hennessy NLM. Computed tomography whole body imaging in multi-trauma: 7 years experience. Clin Radiol 2006;61:365-9.

16. Belabbas D, Auger M, Lederlin M, et al. Whole-Body CT after Motor Vehicle Crash: No Benefit after High-Energy Impact and with Normal Physical Examination. Radiology 2019;292:94-100.

17. Sierink JC, Saltzherr TP, Beenen LFM, et al. A case-matched series of immediate total-body CT scanning versus the standard radiological workup in trauma patients. World J Surg 2014;38:795-802.

18. Qamar SR, Evans D, Gibney B, et al. Emergent Comprehensive Imaging of the Major Trauma Patient: A New Paradigm for Improved Clinical Decision-Making. Can Assoc Radiol J 2020:846537120914247.

19. Babaud J, Ridereau-Zins C, Bouhours G, et al. Benefit of the Vittel criteria to determine the need for whole body scanning in a severe trauma patient. Diagnostic and Interventional Imaging 2012;93:371-9. 